\title{
Experimental Evaluation of Performance of Constant Power Prime-Mover Driven Isolated 3- $\varphi$ SEIG for Pico-Hydro Power Generation System in Remote Mountainous Region of Himalayas
}

\author{
Umesh C. Rathore ${ }^{1, a}$ and Sanjeev Singh ${ }^{2}$ \\ ${ }^{1}$ Electrical Engineering Department, ABV Government IET Pragatinagar, Shimla, HP, India \\ ${ }^{2}$ Electrical \& Instrumentation Engineering Department, SLIET Longowal, Punjab, India
}

\begin{abstract}
This paper presents the experimental evaluation of the performance of 3- $\varphi$ self-excited induction generator (SEIG) suitable for pico-hydro power generation system feeding domestic load in remote mountainous region. The use of induction generators is most suitable for renewable energy conversion systems due to their enormous advantages over conventional synchronous generators. Important features of induction generators include the simplicity in construction, ruggedness, simplified control, ease in maintenance and small size per generated $\mathrm{kW}$. The performance characteristics of 3- $\varphi$ SEIG feeding isolated load are evaluated using MATLAB-Simulink model based on the prevalent renewable energy sources inputs and loading conditions in mountainous terrain of Himalayas. The results are validated using an experimental set-up comprising of 3- $\varphi, 3 \mathrm{HP}$ induction motor run as 3- $\varphi$ induction generator driven by $5 \mathrm{HP}, 4$-pole $\mathrm{DC}$ shunt motor acting as prime-mover.
\end{abstract}

\section{Introduction}

In the present energy scenario across the world, greater emphasis is being given nowadays on harnessing the vast energy potential of various renewable energy sources available across the world. Harnessing of renewable energy potential is essential to meet the ever increasing demand of electrical energy across the globe and also to minimize the adverse impact on environment caused by various conventional energy sources such as coal and petroleum products. With the rapid advancement in technology, the harnessing of these alternate sources of energy such as wind, hydro, geothermal, tidal, biomass, ocean thermal etc has become easier. These renewable energy sources are best suited to compliments the conventional sources of energy and also to meet the energy demand of the population living in remote areas where proving electricity using conventional grid is difficult. About $20 \%$ of the global final energy consumption comes from renewable sources.

Hydro energy is the most reliable and cost effective renewable energy source suitable for providing the electrical energy in remote mountainous regions which generally have the vast hydro potential. Along with the large hydro power plants, micro/pico hydro power plants play a significant role in meeting the power requirement. As compared to large hydro, micro/pico hydro power plants are environment friendly and require less investment. An estimated electric power potential of

\footnotetext{
${ }^{a}$ Corresponding author: umeshrathore@sliet.ac.in
}

more than 2, 00,000 MW from small hydro exists worldwide, out of which around 50,000 MW has been tapped so far. India also has a history of more than 100 years in micro/pico hydro with the estimated potential of nearly $5000 \mathrm{MW}$ capacity identified through more than 2000 sites in various states of India. Most of these sites are located in Himalayan region. The capacity of hydro power plants is decided on the basis of hydrology data such as water discharge, $\&$ rainfall for the past few years and water head available on the selected site. In hydro power plants, the erratic rainfall affects the water discharge in catchment areas which further affects the generated $\mathrm{kWh}$ output. However, the effect of water discharge variation is less on pico hydro power plants as most of these hydro power plants use uncontrolled hydroturbines with the continuous availability of required water discharge. Most of these pico hydro power plants are located in the remotest part of the mountainous region feeding isolated load for small habitats having small electrical load. Pico hydro power plants in isolated mode are suited to these remote locations which are difficult to connect with conventional grid. The daily electrical load pattern varies during 24 hours in remote areas as most of the electrical load comprises of lighting and heating which is switched on and off as per the requirement.

To analyse the electrical loading pattern in the rural remote areas, data was collected from a $33 / 11 \mathrm{kV}$ electrical sub-stations feeding the remote villages using various $11 \mathrm{kV}$ distribution feeder lines in the District of Chamba in the state of Himachal Pradesh, India. Fig. 1 
shows the electrical loading pattern as the per logged data collected from various $11 \mathrm{kV}$ feeders feeding the rural villages during the winter and summer months of 2015 .

Daily Electrical Loading Profile in Remote Mountainous Region

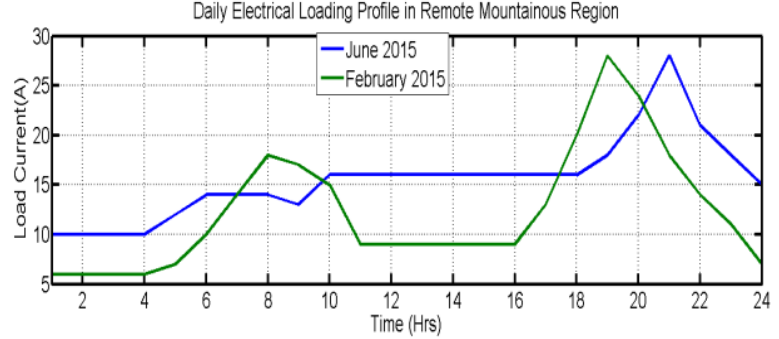

Figure 1. Electrical loading pattern in remote hilly regions.

Most of the electrical load in these areas comprises of lighting and heating load along with very few motor load of floor mills that too operate mostly in day times.From the loading pattern as shown in Fig. 1, it is clear that during the evening time between 6 PM to $10 \mathrm{PM}$, load is maximum with peak loading at around $8 \mathrm{PM}$. While the load is minimum during 2400 hours mid night to $5 \mathrm{AM}$ and which is about $15 \%$ of the maximum load. This loading pattern becomes crucial in the case if the rural isolated load is fed from a pico/micro hydro power plant and which is not connected to the grid. Under such varying load conditions, the use of suitable technologies on power generation such as use of induction generators [1] is beneficial due to their adaptability to variation in load and to keep voltage and frequency constant.

This paper presents the suitability of small rated induction generators $(<10 \mathrm{~kW})$ in the remote mountainous terrain after evaluating the performance characteristics of these small induction generators using MATLAB/Simulink based models emulating the prevalent renewable inputs and varying isolated load conditions in remote mountainous regions. The simulated results are validated using an experimental setup comprising of $3 \mathrm{HP}, 4$ pole, $415 \mathrm{~V}, 3-\varphi$, squirrel cage induction motor operated as 3- $\varphi$ self-excited induction generator driven by a 5 HP DC shunt motor acting as prime-mover. For self-excitation of SEIG, a 3-phase capacitor bank with different required ratings of capacitors in star and delta mode has been used. For electrical loading of self-excited induction generator, a 3phase lamp load has been used. A single/3-phase inductive load has also been used for inductive loading. The performance parameters of SEIG have been evaluated at no load and at different load (balanced \& unbalanced load) emulating the prevalent isolated load conditions in remote mountainous regions based on data.

\section{Self-excited induction generators}

Difference between induction generator and induction motor lies in the rotor speed. In induction generator the rotor speed is more than the synchronous speed while in induction motor, the rotor speed is slightly less than the synchronous speed. Induction generator consumes reactive power rather than supplying it and supplies only the real power $(\mathrm{kW})$ to the system to which it is connected. The $\mathrm{kVAr}$ required by the induction generator plus the kVAr requirements for all other loads on the system must be supplied from static capacitors. Broadly the induction generators can be classified [2]-[3] as Self Excited Induction Generator (SEIG), Doubly Fed Induction Generator (DFIG) and Permanent Magnet Induction Generator (PMIG). Self excited induction generator is suitable for micro or pico hydro power plants located in remote areas to feed an isolated load. In standalone SEIG, the reactive power must be fed externally using capacitors as shown in Fig. 2 to establish the required magnetic field.
$P_{L}$

(Active Power to Load)

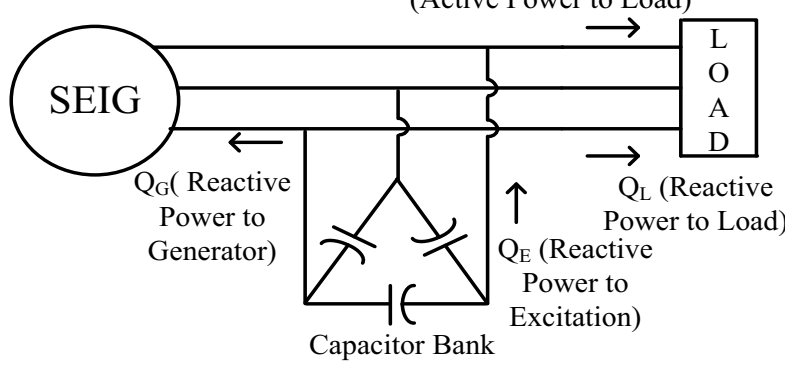

(a)

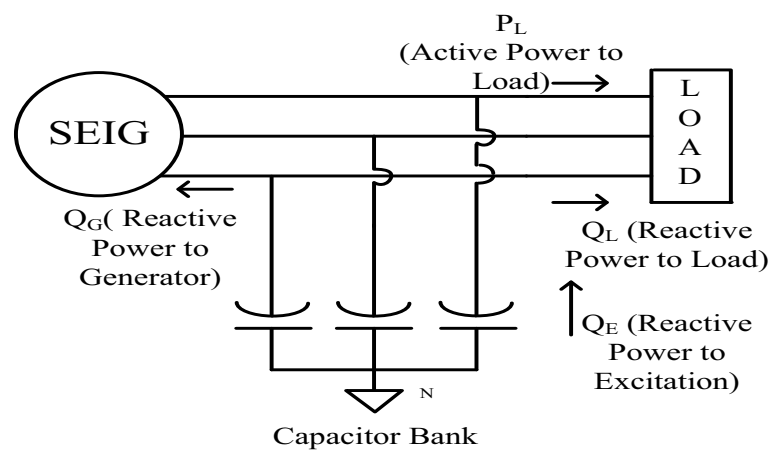

(b)
Figure 2. 3- $\varphi$ SEIG with (a) delta connected capacitor bank, (b) with star connected capacitor bank.

Capacitors bank is connected in parallel with the induction generator terminals either in star or delta mode. When the rotor speed exceeds the synchronous speed, the residual magnetic field in the rotor initiates a voltage across the SEIG terminals and further augmented by the capacitor current to reinforce the magnetic field and system builds up an increasing excitation. After that with the increase in speed, the capacitor impedance decreases and excitation increases which results in increase in terminal voltage of the induction generator till the voltage is limited by saturation of magnetic circuit of the induction machine. To built up the voltage; there must be some residual magnetism present in the rotor of induction generator. The exact requirement of the capacitance depends upon the value of $\mathrm{kVAr}$ required and value of this capacitance is calculated in number of ways [4]-[10]. The minimum capacitance is inversely proportional to the square of speed and to the maximum saturated magnetizing reactance. The value of the capacitance is affected by load impedance, power factor and speed of induction machine. The maximum power output from the isolated SEIG depends upon its terminal capacitance and 
the speed of the generator. There must be a threshold speed called cut-off speed below which no excitation is possible, whatever the capacitor value may be. The main aim of the control strategies for induction generators is to regulate or maintain the desired voltage and frequency of the generated output. This is achieved using electronic load controller as shown in Fig. 3. The main function of the electronic load controller in isolated pico-hydro power plant using SEIG is to maintain the output load constant as seen by the induction generator under different consumer load conditions. The SEIG feeds two loads connected in parallel. The main load is consumer load and other load is dump or auxiliary load where power dissipated is generally wasted but can be used for other useful purposes such as pumping of water etc [11]. The electronic chopper in the controller circuit regulates the real \& reactive power so that load seen by the generator is always constant. The conventional ELCs have discontinuous nature of control with discrete steps in connecting and disconnecting dump load which results in power quality problems. Modern electronic load controller technology has to meet the demand of various types of consumer loads which may be linear, non-linear, balanced or unbalanced and also has to maintain the power quality standards [12]-[15].

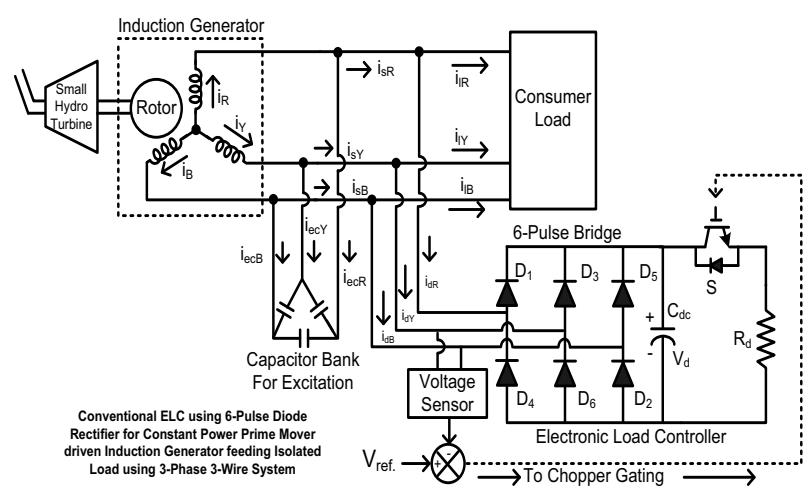

Figure 3. Electronic load controller circuit for isolated 3-phase SEIG in pico-hydro power generation system.

\section{Simulated performance of SEIG in pico-hydro power generation system}

Before experimental validation of SEIG, performance characteristics of the SEIG under steady state condition were simulated using MATLAB-Simulink based model of a 3- $\varphi$ induction machine of 3 H.P, 415 Volts, 4-Poles rating which is actually used in real time practical application. The main component in the SEIG system is the selection of capacitance required for proper operation of SEIG under different operating conditions. After selecting the rating of capacitor bank connected in delta, various simulation tests were conducted under steady state condition of rated voltage and speed. The effect on value of capacitance was observed using simulation under different operating conditions such as variation in speed, variation in power factor due to change in inductive load and under different loading conditions. Results show the voltage build-up at a required capacitance and also the capacitance requirement is inversely proportional to square of speed. Also the capacitance value increases with the decrease in power factor it is also affected by the change in load. For the rated generated voltage, the value of excitation capacitance is slightly less than the value required at certain load. The terminal voltage is affected by the change in load. As the load on SEIG increases, its terminal voltage decreases slightly. The MATLAB/Simulink based simulation model and some of the simulated results such as terminal voltage development and its variation at change in load, variation of capacitance at different load and power factors and effect of change in load on SEIG voltage are shown in Figures 4 to 7 . In the simulated model, the consumer load, controller circuit and measurement sections are shown as sub-systems.

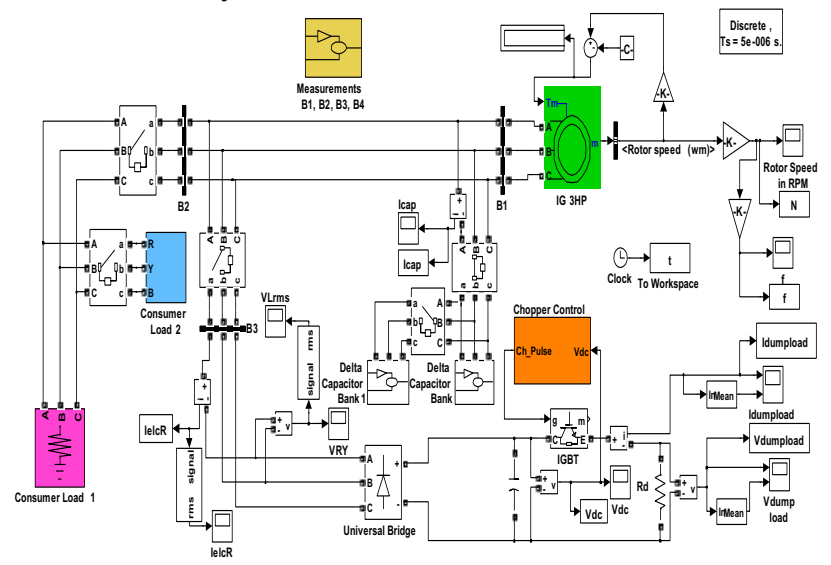

Figure 4. MATLAB/Simulink based model of 3 HP SEIG in isolated pico-hydro power generation system.

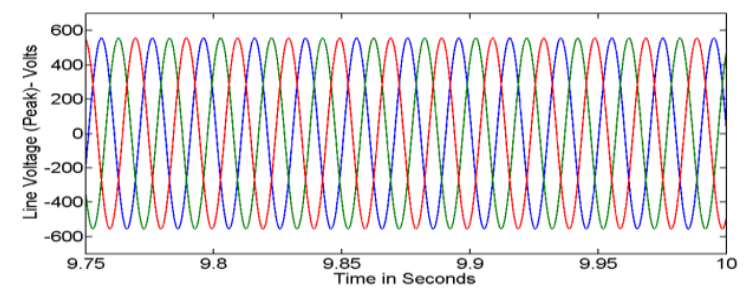

Figure 5. Generated 3-phase output voltage of SEIG.

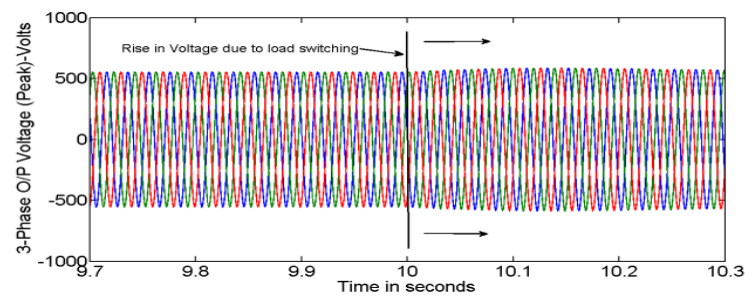

Figure 6. Variation in terminal voltage with change in load.

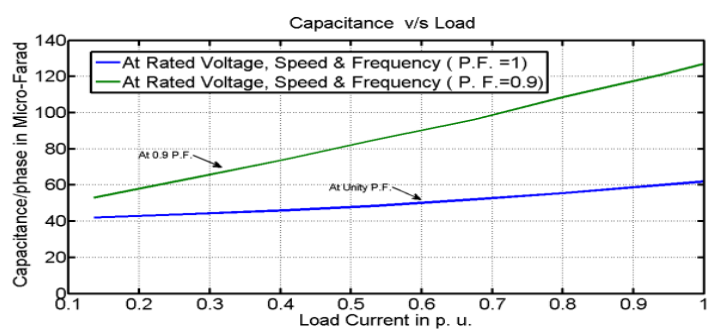

Figure 7. Capacitance v/s load current curves. 


\section{Experimental verification of performance of 3- $\varphi$ SEIG in pico-hydro power generation system}

To validate the simulated results and to prove the efficacy and suitability of self-excited induction generator feeding isolated load in pico-hydro power generation system, a hardware setup was prepared for experimentation. Figure 8 shows the photographs of the complete experimental set-up. The keys components of the hardware set-up consists of 3-phase, $415 \mathrm{~V}, 4$ pole, $50 \mathrm{~Hz}$ squirrel cage induction motor operated as 3-phase SEIG coupled with a 5HP, DC shunt motor acting as prime-mover, a 3phase/1-phase capacitor bank comprising of 10 sets of $6 \mu \mathrm{F}$ capacity $600 \mathrm{~V}$ capacitors on each phase which can be connected either in delta or star mode with their individual circuit breakers, individual control panels for induction machine and DC machine operation and a set of 3-phase resistive and inductive load. The data logging and metering equipment include the speed sensor, suitable digital meters on panels for voltage and current measurement, a power meter (Yokogawa make) for voltage, current, power, frequency, power factor and total harmonics distortion (THD) measurements. The 3-phase resistive load panel comprised of 8 lamp loads on each phase. The inductive load used is of 3-phase type having $5 \mathrm{~A}, 415 \mathrm{~V}$ rating.

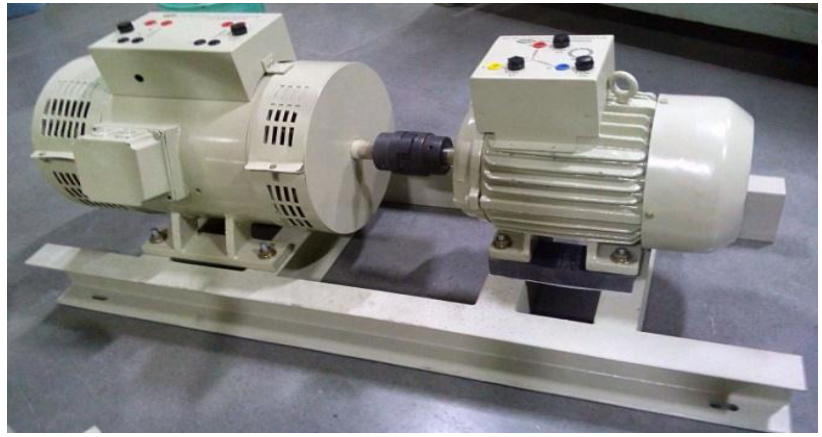

(a)

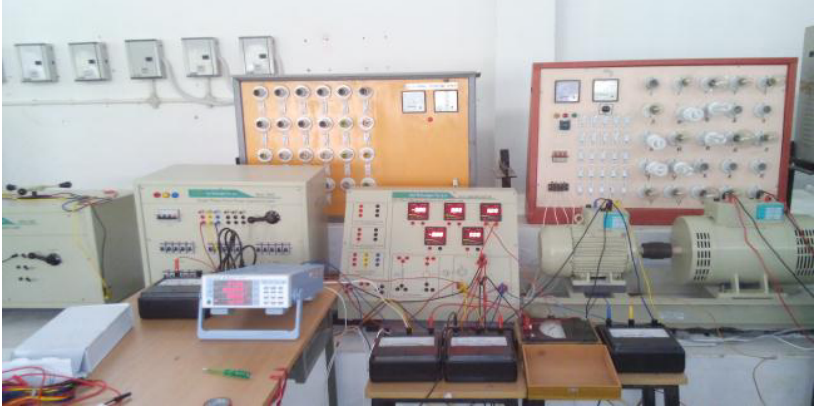

(b)

Figure 8. Hardware setup: (a) Induction machine coupled with prime-mover, (b) complete experimental set-up.

The complete trial for operating the 3-phase induction motor as induction generator was done in the following sequence:

- Running the induction machine first as induction motor for few hours to initiate the residual magnetic field.

- Driving the induction machine with the help of primemover (DC shunt machine in the adopted set-up) at its rated speed for few minutes. The speed of prime-mover is then increased to run the 3-phase induction motor at above the synchronous speed (1500 RPM for 4-pole machine). In this set-up, induction machine is driven at 1550 RPM for few minutes without connecting the capacitor bank across SEIG terminals.

- Connect all the measurement devices to record the induction generator parameters at various excitation capacitance values and at different speed.

- Firstly the induction generator is at no load. Under this condition, first set of excitation capacitor bank (in delta or star mode) is switched ON to build the no-load voltage across induction generator terminals. The value of the connecting capacitor banks is increased in steps until the required voltage is build up.

- Once the required voltage is build-up, load is switched $\mathrm{ON}$ across the SEIG and then its effect on the generator speed, voltage, power factor and excitation capacitance is recorded under different operating conditions.

\subsection{Voltage build-up process in 3- $\varphi$ SEIG using excitation capacitance}

After running the induction machine at slightly higher than its synchronous speed, a first set of excitation capacitance $(6 \mu \mathrm{F} /$ phase in this set-up) is switched ON and then the voltage at the terminals of induction machine was observed. Full voltage development across the SEIG terminals used in the experiment recorded when $12 \mu \mathrm{F} /$ phase excitation capacitance in delta mode is connected for 3 HP rated induction generator at no load. The voltage developed at no load is slightly higher than the rated voltage of induction machine, but when load is put on the generator, it falls and can be brought to its rated value by accurately varying the excitation capacitance value. The exact value of the connected capacitor as shown in Table I can also be calculated by recording the stator terminal voltage and capacitor line current readings recorded during the experimentation. In this experiment, the connected capacitance value in the capacitor bank in delta exactly matched with the calculated value of excitation capacitance experimentally.

\subsection{Experimental evaluation of $3-\varphi$ SEIG under loaded conditions}

Most of the consumer load in remote mountainous regions generally comprises of domestic lighting and heating load involving incandescent and compact fluorescent lamps. Apart from this some domestic load for a very short period consists of electronic gadgets and house-hold single phase appliances. There is no industrial load except for the use of induction machines in few flour mills. In this experimental set-up, a three phase lamp load with multiple loading steps for each phase was used to connect the lamp load on each phase. In present energy scenario with greater emphasis on energy conservation, there is a maximum use of compact fluorescent lamps (CFLs) in almost every house-hold. Keeping this in view, the CFLs were also used along with conventional incandescent lamps to evaluate the performance of SEIG. Table II shows the experimental recorded parameters. 
Table 1. Experimental calculation of excitation capacitance per phase in delta mode.

\begin{tabular}{|c|c|c|c|c|c|c|c|c|c|c|}
\hline \multicolumn{4}{|c|}{$\begin{array}{l}\text { 3- } \varphi, \text { Star connected } \\
\text { Resistive Lamp Load } \\
\text { (Watts) across SEIG }\end{array}$} & \multirow{2}{*}{$\begin{array}{l}\text { Capacitanc } \\
\text { e/Phase in } \\
\text { Delta } \\
\text { mode }(\mu F)\end{array}$} & \multirow{2}{*}{$\begin{array}{c}\text { Cap. } \\
\text { bank } \\
\text { Line } \\
\text { Voltage } \\
\text { (V) }\end{array}$} & \multirow{2}{*}{$\begin{array}{c}\text { Cap. } \\
\text { bank } \\
\text { Line } \\
\text { Current } \\
\text { (A) }\end{array}$} & \multirow{2}{*}{$\begin{array}{c}\text { Cap. } \\
\text { bank } \\
\text { Phase } \\
\text { Current } \\
\text { (A) }\end{array}$} & \multirow{2}{*}{$\begin{array}{l}\text { Calculated } \\
\text { value of } \\
\text { Capacitanc } \\
\text { e/Phase } \\
(\mu \mathrm{F}) \\
\end{array}$} & \multirow{2}{*}{$\begin{array}{c}\text { Frequency } \\
\text { of } \\
\text { Generated } \\
\text { Voltage }\end{array}$} & \multirow[t]{2}{*}{$\begin{array}{l}\text { SEIG Speed } \\
\text { in RPM }\end{array}$} \\
\hline $\mathrm{R}_{\mathrm{ph}}$ & $\mathrm{Y}_{\mathrm{ph}}$ & $\mathrm{B}_{\mathrm{ph}}$ & Total & & & & & & & \\
\hline 0 & 0 & 0 & 0 & 12 & 455 & 3.10 & 1.79 & 12.09 & 49.8 & 1522 \\
\hline 100 & 100 & 100 & 300 & 12 & 431 & 2.89 & 1.67 & 11.9 & 49.8 & 1518 \\
\hline 200 & 200 & 200 & 600 & 12 & 415 & 2.75 & 1.59 & 12.1 & 49.6 & 1512 \\
\hline
\end{tabular}

Table 2. Experimental values of SEIG \& prime-mover parameters under different operating conditions.

\begin{tabular}{|c|c|c|c|c|c|c|c|c|c|c|c|c|c|c|c|}
\hline \multicolumn{4}{|c|}{$\begin{array}{l}\text { 3- } \varphi, \text { Star connected } \\
\text { Resistive Lamp Load } \\
\text { (Watts) across SEIG }\end{array}$} & \multirow{2}{*}{$\begin{array}{c}\mathrm{C} / \\
\mathrm{ph} \\
(\mu \mathrm{F}) \\
\text { Delt } \\
\mathrm{a} \\
\text { Mod } \\
\mathrm{e} \\
\end{array}$} & \multirow{2}{*}{$\begin{array}{l}V_{L L} \\
(V)\end{array}$} & \multirow{2}{*}{$\begin{array}{c}\mathrm{I}_{\mathrm{L}} \\
\text { SEI } \\
\text { G } \\
\text { Line } \\
\text { Curr } \\
\text { ent } \\
\text { (A) }\end{array}$} & \multirow{2}{*}{$\begin{array}{l}\mathrm{I}_{\mathrm{L}(\mathrm{C})} \\
\text { Cap. } \\
\text { Line } \\
\text { Curre } \\
\text { nt (A) }\end{array}$} & \multirow{2}{*}{$\begin{array}{l}\mathrm{I}_{\mathrm{ph}} \\
(\mathrm{Loa} \\
\mathrm{d}) \\
\text { (A) }\end{array}$} & \multirow{2}{*}{$\begin{array}{c}\mathrm{N} \\
(\mathrm{RPM} \\
\quad)\end{array}$} & \multirow{2}{*}{$\mathrm{PF}$} & \multirow{2}{*}{$\begin{array}{c}F \\
(\mathrm{~Hz})\end{array}$} & \multicolumn{4}{|c|}{$\begin{array}{c}\text { Prime Mover } \\
\text { (DC Shunt Motor) } \\
\text { Parameters }\end{array}$} \\
\hline $\begin{array}{c}\mathrm{R} \\
\mathrm{ph}\end{array}$ & $\begin{array}{c}\mathrm{Y} \\
\mathrm{ph}\end{array}$ & $\begin{array}{c}\text { B } \\
\text { ph }\end{array}$ & $\begin{array}{c}\text { Tota } \\
1\end{array}$ & & & & & & & & & $\begin{array}{l}\mathrm{V}_{\mathrm{A}} \\
(\mathrm{V})\end{array}$ & $\begin{array}{l}\mathrm{V}_{\mathrm{F}} \\
(\mathrm{V})\end{array}$ & $\begin{array}{c}\mathrm{I}_{\mathrm{A}} \\
(\mathrm{A})\end{array}$ & $\begin{array}{c}\mathrm{I}_{\mathrm{F}} \\
(\mathrm{A})\end{array}$ \\
\hline 0 & 0 & 0 & 0 & 6 & 0 & 0 & 0 & 0 & 1550 & 1 & - & 210 & 186 & 0.9 & 0.73 \\
\hline 0 & 0 & 0 & 0 & 12 & 470 & 3.27 & 3.21 & 0 & 1552 & 1 & 50.8 & 209 & 185 & 2.5 & 0.70 \\
\hline 100 & 100 & 100 & 300 & 12 & 447 & 3.11 & 3.0 & 0.49 & 1539 & 0.99 & 50.3 & 208 & 183 & 4.3 & 0.69 \\
\hline 200 & 200 & 200 & 600 & 12 & 425 & 3.02 & 2.82 & 0.95 & 1535 & 0.95 & 50.1 & 208 & 182 & 5.4 & 0.69 \\
\hline 300 & 300 & 300 & 900 & 12 & 410 & 2.95 & 2.65 & 1.31 & 1527 & 0.94 & 49.8 & 207 & 182 & 6.9 & 0.68 \\
\hline 340 & 0 & 320 & 660 & 12 & 445 & 3.28 & 3.0 & 1.35 & 1564 & 0.92 & 51.3 & 214 & 189 & 6.0 & 0.69 \\
\hline 400 & 400 & 400 & 1200 & 12 & 385 & 2.92 & 2.50 & 1.52 & 1525 & 0.95 & 49.5 & 208 & 182 & 7.4 & 0.67 \\
\hline 400 & 400 & 400 & 1200 & 12 & 416 & 3.20 & 2.65 & 1.60 & 1574 & 0.84 & 51.5 & 217 & 187 & 8.0 & 0.69 \\
\hline 500 & 500 & 500 & 1500 & 12 & 355 & 2.88 & 2.30 & 1.77 & 1559 & 0.85 & 51 & 215 & 188 & 7.7 & 0.65 \\
\hline 500 & 500 & 500 & 1500 & 18 & 415 & 3.03 & 2.7 & 1.9 & 1450 & 0.85 & 46.8 & 203 & 194 & 11 & 0.68 \\
\hline
\end{tabular}

Table 3. Experimental values of SEIG parameters under different resistive \& inductive loads.

\begin{tabular}{|c|c|c|c|c|c|c|c|c|c|c|c|c|c|}
\hline \multicolumn{4}{|c|}{$\begin{array}{l}\text { 3- } \varphi \text {, Star connected } \\
\text { Resistive Lamp Load } \\
\text { (Watts) across SEIG }\end{array}$} & \multicolumn{3}{|c|}{$\begin{array}{c}\text { Parameters of 3- } \varphi \text {, } \\
\text { Star connected } \\
\text { Inductive Load across } \\
\text { SEIG }\end{array}$} & \multirow{2}{*}{$\begin{array}{c}\text { C/ph } \\
(\mu \mathrm{F}) \\
\text { in } \\
\text { Delta } \\
\text { Mode }\end{array}$} & \multirow{2}{*}{$\begin{array}{c}\mathrm{V}_{\text {LL }} \\
(\mathrm{V}) \\
\text { SEIG } \\
\text { Terminal } \\
\text { Voltage }\end{array}$} & \multirow{2}{*}{$\begin{array}{c}\text { I }_{\mathbf{L}} \\
\text { (A) } \\
\text { SEIG } \\
\text { Line } \\
\text { current }\end{array}$} & \multirow{2}{*}{$\begin{array}{c}\mathbf{I}_{\mathbf{L}(\mathbf{C})} \\
\text { (A) } \\
\text { Cap. } \\
\text { Circuit } \\
\text { Line } \\
\text { Current }\end{array}$} & \multirow{2}{*}{$\begin{array}{c}\mathbf{I}_{\mathrm{ph}} \\
(\mathrm{Load}) \\
(\mathrm{A}) \\
\text { Load } \\
\text { Phase } \\
\text { Current }\end{array}$} & \multirow[t]{2}{*}{$\begin{array}{l}\text { N } \\
\text { (RP } \\
\text { M) }\end{array}$} & \multirow[t]{2}{*}{$\begin{array}{c}\text { F } \\
(\mathbf{H z} \\
)\end{array}$} \\
\hline $\begin{array}{l}\text { R } \\
\text { ph }\end{array}$ & $\begin{array}{l}Y \\
\text { ph }\end{array}$ & $\begin{array}{l}\text { B } \\
\text { ph }\end{array}$ & Total & $\begin{array}{l}V_{L L} \\
(V)\end{array}$ & $\begin{array}{c}I_{L} \\
(A)\end{array}$ & $\begin{array}{c}\mathbf{Q} \\
\text { (kVAr) }\end{array}$ & & & & & & & \\
\hline 100 & 100 & 100 & 300 & 0 & 0 & 0 & 12 & 443 & 3.11 & 3.0 & 0.49 & 1539 & 50.2 \\
\hline 100 & 100 & 100 & 300 & 452 & 1.21 & 0.95 & 18 & 452 & 3.39 & 3.02 & 0.49 & 1522 & 49.8 \\
\hline 200 & 200 & 200 & 600 & 438 & 1.15 & 0.88 & 18 & 436 & 3.35 & 3.1 & 0.98 & 1518 & 49.7 \\
\hline 400 & 400 & 400 & 1200 & 390 & 1.03 & 0.70 & 18 & 390 & 3.28 & 2.55 & 1.52 & 1510 & 48.8 \\
\hline 400 & 400 & 400 & 1200 & 427 & 1.11 & 0.82 & 18 & 427 & 3.4 & 2.90 & 1.50 & 1545 & 50.2 \\
\hline
\end{tabular}


Following inferences were made out of this experimentation:

- A minimum value of excitation capacitance is required to build up the voltage at SEIG terminals on no load. In this case for $3 \mathrm{HP}$, 4-pole SEIG the terminal voltage built-up at $12 \mu \mathrm{F} /$ phase in delta connected capacitor bank. - As the electrical load on SEIG is increased, its terminal voltage slightly falls along with the slight drop in the speed of induction generator. However, the decrease in terminal voltage due to increase in load can be compensated by increasing the speed of prime mover.

- With the further increase in electrical load, requirement of excitation capacitance increases at rated speed.

- Since domestic electrical load is of single-phase type and 3-phase, 4-wire system is used for electrifying the villages which results in the un-balancing of load in each phase. Therefore, unequal loading was done for SEIG in the experiment and it was observed that the SEIG parameters remained within the permissible limit.

- When a 3-phase inductive load along with resistive load was put on the SEIG, the requirement of the excitation capacitance increased to compensate for the lagging reactive power caused by the inductive load. Table III shows the SEIG parameters recorded under resistive and inductive load.

\section{Conclusion}

The performance characteristics of 3-phase SEIG operated in isolated mode have been investigated in the presented paper and results are validated using an experimental setup. These tests have been performed without the use of electronic load controller. But in actual practice, these controllers are used to maintain and control the voltage and frequency of the system where voltage is regulated by controlling the reactive power using STATCOM and the frequency is maintained by controlling the dump load. However, in the tests by regulating the DC shunt motor parameters, the constant power input conditions has been emulated. The experimental results validate the efficacy and suitability of self-excited induction generator for feeding the isolated load in remote locations as it adapts well to counter the varying loading conditions. During off-load period, the wasted energy across dump load can be utilized for useful purpose such as pumping of water to meet the potable and irrigation requirement.

\section{Acknowledgement}

Authors sincerely thank the management of Himachal Pradesh State Electricity Board Limited to collect the daily electrical load data from their $33 \mathrm{kV} / 11 \mathrm{kV}$ substations feeders feeding the remote locations presented in this paper.

\section{References}

1. M. Godoy Simoes and Felix A. Farret, Alternate Energy Systems: Design and Analysis with Induction Generators, 2nd ed. Boca Raton: CRC Press (2008)
2. R. C. Bansal, "Three-phase self-excited induction generators: an overview," IEEE Transactions on Energy Conversion, vol. 20, pp. 292-299 (2005).

3. M. H. Haque, "Self-excited single-phase and threephase induction generators in remote areas," in Proc. IEEE ICECE'08, pp. 38-42 (2008).

4. S. S. Murthy, O. P. Malik, and A. K. Tandon, "Analysis of self-excited induction generator," Proc. Inst. Elect. Eng. C, vol. 129, no. 6, pp 260-265, (1982).

5. S.P. Singh, B. Singh, and M. P. Jain, "Comparative study on the performance of a commercially designed induction generator with induction motors operating as self excited induction generators," IEE Proceeding -C, vol. 140, no. 5, pp. 374-380, ( 1993).

6. A. K. Al Jabri and A. I. Alolah, "Capacitance requirement for isolated self-excited induction generator," IEE Proc. Electr. Power Appli., vol. 137, no. 3, pp. 154-159 (1990).

7. T. F. Chan, "Capacitance requirements of selfexcited induction generators," IEEE Transactions on Energy Conversion, vol. 8, no. 2, pp. 304-311 (1993).

8. L. Shridhar, B. Singh, C. S. Jha, B. P. Singh, and S. S. Murthy, "Selection of capacitors for the self regulated short shunt self excited induction generator," IEEE Transactions on Energy Conversion, vol. 10, no. 1, pp. 10-17 (1995).

9. V. P. Chandran and S. Vadhera, "Capacitance requirements of self excited induction generator for different operating conditions," in Proc. IEEE ICEAS, pp. 1-6 (2011).

10. S. Kulandhaivelu, K. K. Ray, P. Jyothi, S. Jayachitra, and V. Narasinga Rao, "Experimental evaluation of capacitance value; to self-excite the induction motor operating as generator in wind energy conversion," in Proc. IEEE ICETECT'11, pp. 133-140 (2011).

11. Umesh C. Rathore and Sanjeev Singh, "Isolated 3phase self-excited induction generator in pico-hydro power plant using water pump load in mountainous region of Himalayas," in Proc. 2014 IEEE Global Humanitarian Technology Conference - South Asia Satellite (GHTC-SAS), pp. 40-44 (2014)

12. K. Idjdarene, D. Rekioua, T. Rekioua, and A. Tounzi, "Performance of an isolated induction generator under unbalanced loads," IEEE Transactions on Energy Conversion, vol. 25, no. 2, pp. 303-311(2010)

13. E. Suarez and G. Bortolotto, "Voltage-frequency control of a self excited induction generator," IEEE Transactions on Energy Conversion, vol. 14, no. 3, pp. 394-401(1999)

14. B. Singh, S. S. Murthy, and S. Gupta, "Analysis and design of STATCOM-based voltage regulator for self-excited induction generators," IEEE Transactions on Energy Conversion, vol. 19, no. 4, pp. 783-790(2004)

15. B. Singh and G. K. Kasal, "Voltage and frequency controller for isolated asynchronous generators feeding 3-phase 4-wire loads," in Proc. IEEE ICIT'06, pp. 2773-2778(2006) 